Чістякова Ірина Миколаївна кандидат філософських наук, доцент, зав. каф. «Міжнародних відносин та права» Державного університету «Одеська політехніка», пр. Шевченко, 1, м. Одеса, 65044, тел.: (050) 49053-94, e-mail: i.m.chistyakova@opu.ua, https://orcid.org/0000-0002-0182-9334

Кудлай Ірина Володимирівна старший викладач кафедри «Міжнародних відносин та права» Державного університету «Одеська політехніка», пр. Шевченко, 1, м. Одеса, 65044, тел.: (050) 175-71-56, еmail: kiv@ opu.ua, https://orcid.org/0000-0002-6154-5245

Гайтан Віталій Віталійович кандидат політичних наук, старший викладач кафедри «Міжнародних відносин та права» Державного університету «Одеська політехніка», пр. Шевченко, 1, м. Одеса, 65044, тел.: (050) 175-71-56, e-mail: haitan.v.v@opu.ua , https://orcid.org/0000-0002$6967-202 X$

\title{
АНАЛІЗ ДОСЛІДЖЕНЬ ПОЛІТИЧНОЇ ВЗАЕМОДІЇ У МІЖНАРОДНИХ КОНФЛІКТАХ
}

Анотація. У статті проводиться теоретико-методологічний аналіз досліджень в області міжнародних конфліктів, який дозволяє побачити істотні зміни, які відбуваються в даному науковому напрямку в сучасний час, розглядаються минулі і справжні зусилля, що спрямовані на поліпшення діяльності 3 попередження конфліктів і використовуваних при аналізі проблем впливу на конфлікт. Обговорюються проблеми міжнародних конфліктів та методи їх запобігання. Формується уявлення про те, як змінювалися погляди на конфлікт в різні епохи, яка роль відводилася конфлікту в тих чи інших наукових концепціях. Звертається увага на період другої половини XIX - XX ст., коли сформувався науковий підхід до дослідження конфліктів, відбулося становлення конфліктологічної парадигми вивчення суспільства. Дослідження в області конфліктології залишаються вкрай актуальними, але їх сутність все більше набуває політичного забарвлення. Причинами $є$ зростання міжнаціонального екстремізму, розростання ісламського фундаменталізму, збільшення числа внутрішньодержавних конфліктів i багато іншого. Ситуація, що склалася в світі вимагає вдосконалення підходів і способів регулювання міжнародних конфліктів, формування нової концепції i моделі управління конфліктами за допомогою сучасних інтелектуальних засобів підтримки прийняття рішень. При вирішенні проблем існуючих міжнародних конфліктів особливу увагу варто приділити передумовам виникнення політичних конфліктів, їх ідеологічної природі, алгоритму їх 
оперативного управління. В статті проаналізовані уявлення про методологічні особливості вивчення політичних конфліктів.

Аналіз існуючих класифікацій міжнародних конфліктів дозволяють розробити єдину модель міжнародного конфлікту, яка об'єднала схожі складові частини різних за типом конфліктних ситуацій.

Ключові слова: Міжнародні відносини, міжнародний конфлікт, міжнародна криза, запобігання міжнародного конфлікту, конфліктологія міжнародних відносин, види конфліктів, війна, збройний конфлікт, врегулювання конфлікту, розв'язування конфлікту, миротворча операція.

Chistyakova Iryna Mykolayivna Candidate of Philosophy Sciences, Assoc. Prof., Head kaf. "International Relations and Law" of the State University "Odessa Polytechnic", Shevchenko Ave., 1, Odessa, 65044, tel.: (050) 490-53-94, e-mail: i.m.chistyakova@opu.ua, https://orcid.org/0000-00020182-9334

Kudlai Iryna Volodymyrivna Senior lecturer of the department "International Relations and Law" of the State University "Odessa Polytechnic", Shevchenko Ave., 1, Odessa, 65044, tel.: (050) 175-71-56, e-mail: kiv@opu.ua https://orcid.org/0000-0002-6154-5245

Gaitan Vitaliy Vitaliyovych Candidate of political sciences, senior lecturer of the department "International Relations and Law" of the State University "Odessa Polytechnic", Shevchenko Ave., 1, Odessa, 65044, tel.: (050) 175-71-56, e-mail: haitan.v.v@opu.ua , https://orcid.org/0000-0002-6967$202 X$

\section{THE ROLE OF ACTORS AS A SPECIAL FORM OF POLITICAL INTERACTION IN INTERNATIONAL CONFLICTS}

Abstract. The article provides a theoretical and methodological analysis of research in the field of international conflicts, which allows us to see the significant changes taking place in this scientific field in modern times, considers past and present efforts to improve conflict prevention and used in the analysis of problems conflict. Problems of international conflicts and methods of their prevention are discussed. An idea is formed about how views on conflict have changed in different eras, what role was assigned to conflict in certain scientific concepts. Attention is drawn to the period of the second half of the XIX - XX centuries, when the scientific approach to the study of conflicts was formed, the formation of the conflictological paradigm of the study of society took place. Research in the field of conflict studies remains extremely relevant, but their essence is becoming increasingly political. The reasons are the growth of interethnic extremism, the growth of Islamic fundamentalism, the increase in the number of internal conflicts and much more. The current situation in the world requires the improvement of approaches and methods of managing 
international conflicts, the formation of a new concept and model of conflict management with the help of modern intelligent decision support tools. In solving the problems of existing international conflicts, special attention should be paid to the preconditions for the emergence of political conflicts, their ideological nature, the algorithm of their operational management.

The article analyzes the ideas about the methodological features of the study of political conflicts. Analysis of existing classifications of international conflicts allows us to develop a single model of international conflict, which combines similar components of different types of conflict situations.

Keywords: International relations, international conflict, international crisis, international conflict prevention, conflictology of international relations, types of conflicts, war, armed conflict, conflict settlement, conflict resolution, peacekeeping operation.

Постановка проблеми. Сьогодні дослідження конфліктів є як ніколи актуальним у зв'язку з наростанням напруженості в усьому світі. В будьякій історичний період міжнародні відносини супроводжуються конфліктами, які являють собою закономірне явище в міжнародній системі. Конфлікти продовжують виникати i зараз, та багато 3 них набувають насильницького характеру. Тільки в 1990-х рр. близько 5,5 мільйонів людей загинули майже в 100 збройних конфліктах. Ці смертельні конфлікти призвели до великомасштабних спустошень i нестабільності в регіонах, а також до появи великої кількості біженців. Міжнародна спільнота як і раніше нездатна запобігти війнам, а сфера діяльності багатьох організацій зводиться до обмеження негативних наслідків насильства.

Вже зараз доводиться говорити про «конфлікти нового покоління» в рамках міжнародних відносин. Основним джерелом заклопотаності міжнародного товариства $\epsilon$ його нездатність достовірно i точно передбачати конфлікти, які загрожують набути насильницького характеру, i швидко на них реагувати. Це відбувається як через складну динаміку внутрішніх, етнічних і релігійних конфліктів, так і через небажання держав робити зусилля, які пов'язані 3 великим ризиком i витратами. Проте, наростаюча присутність міжнародних організацій, а також державних i недержавних організацій в зонах, чреватих конфліктами, дає надію на те, що збільшення числа сторін, що беруть участь в попередженні конфліктів, зможе знизити в майбутньому кількість втрачених можливостей.

Взаємозв'язок світових проблем 3 соціальними, економічними $i$ політичними змінами сучасного світу неминуче викликає конфронтацію думок, позицій різних верств населення, соціальних груп, конфесій, суспільних субкультур і т. д.

Слід звернути увагу на те, що міжнародні конфлікти відрізняються від конфліктів у інших сферах суспільного життя в силу властивих самій міжнародній політиці специфічних особливостей. У міжнародних відносинах немає єдиного центру прийняття рішень, обов'язкових для всіх 
учасників цих відносин, тому кожна держава прагне самостійно i незалежно від інших реалізовувати власні інтереси. Зіткнення цих інтересів часто призводить до виникнення конфліктів. У зв'язку з цим представляється необхідним їх своєчасне врегулювання, яке сприяє сталому і гармонійному розвитку суспільства і держави, стабільності та ефективності системи міжнародних відносини.

Аналіз останніх досліджень і публікацій. Вивчення конфліктів у міжнародних відносинах як самостійного напрямку наукових досліджень починається в XX ст. Необхідно відзначити найбільш яскравих представників провідної теорії конфлікту, якими являються такі вітчизняні та зарубіжні науковці, як: Н. Макіавеллі, Карл Дойтч, П. Сорокін, К. Райт, Л. Річардсон, Й. Галтунг, Карл Дж. Якобсон і Кай Ф. Бранд-Якобсон, Л. Крісберг, Дж. Бертон, Т. Мальтус, Г. Спенсер, К. Боулдінг, К. Я. Холсті, Д. Зінгер, Ф. Пфетч і К. Роулофф, Т. Гоббс, Л. Гумплович, У. Самнер. Згадаємо: основні положення вчення К. Маркса про конфлікт; соціальну напруженість в теорії соціальної дії Т. Парсонса; конфліктну модель суспільства Р. Дарендорфа; концепцію позитивно-функціонального конфлікту Л. Козера; психодинамічну модель конфлікту 3. Фрейда, К. Хорні, К. Г. Юнга та ін.. Визначимо значення феномену конфлікту в соціології Г. Зіммеля; дослідження Н. В. Гришиної, роботи А. Г. Здравомислова.

Незважаючи на досить велику кількість робіт, присвячених війнам в попередній період, практично не було робіт, в яких би робилися спроби їх порівняльного аналізу. Початок нового осмислення і вивчення конфліктів було пов'язане зі спробами аналізу великої кількості війн, виділення їх закономірностей на значному періоді історії.

Мета статті - методологічні дослідження в області конфліктології, яке дозволяє побачити істотні зміни, які відбуваються в даному науковому напрямку в сучасний період.

Виклад основного матеріалу. Спочатку розглянемо поняття: міжнародний збройний конфлікт відноситься до ситуацій, в яких беруть участь дві або більше держави, залучених в збройний конфлікт. До національно-визвольної війни відносяться збройні конфлікти, в яких народи борються проти колоніального панування, іноземної окупації i проти расистських режимів, здійснюючи своє право на самовизначення. Внутрішній збройний конфлікт відноситься до всіх збройних конфліктів, які не можна охарактеризувати як міжнародні збройні конфлікти або національно-визвольні війни.

Взагалі кажучи, в міжнародних збройних конфліктах беруть участь різні держави, тоді як в неміжнародних збройних конфліктах беруть участь уряд і повстанські сили на території однієї держави. Ця відмінність не завжди доречна. Після появи безлічі нових держав - в результаті часом насильницької деколонізації - міжнародна спільнота визнала, що певні «внутрішні» конфлікти слід розглядати як міжнародні збройні конфлікти. 
Теоретично існує кілька підходів до аналізу міжнародних відносин. Американський дослідник П. Бекман класифікує всі підходи на історичні та наукові. Однак на практиці найчастіше використовується їх комбінація.

Історичний підхід грунтується на вивченні історичних артефактів, подій, документів, літописів, мемуарів і при цьому особлива увага приділяється розслідуванню та обліку обставин, навколишнього історичного середовища, в якому мали місце події.

Принципова відмінність даного підходу від наукового - це теза про унікальність кожної історичної події і про неможливість іiї виокремлення 3 історичного контексту. Недоліком цього підходу $\epsilon$ неможливість виявлення закономірностей подій і структури міжнародних процесів, а також прогнозування їх розвитку.

3 цієї причини історичний підхід використовується, як правило, на початковому етапі інших підходів для того, щоб отримати найбільш повні вихідні дані для аналізу конфлікту.

Одним із засновників історико-соціологічного підходу є французький соціолог Р. Арон [2]. Р. Арон писав: «тлумачення війн і покарань як санкцій словами «заборонені законом акти»- це тільки юридична фікція, що не відповідає тому сенсу, якого історики, уряди, солдати надавали застосуванню сили» [2, с. 618].

Науковий підхід класифікує події і дозволяє виявляти закономірності міжнародних процесів і прогнозувати їх розвиток. Разом 3 тим, він загрожує абстрагуванням від реальності, спотворенням дійсності i, як наслідок, неможливістю об'єктивного аналізу історичного процесу.

Історія спроб інтерпретації конфлікту налічує тисячоліття. Перші подібного роду спроби були зроблені в Стародавньому Китаї.

Про роль конфліктів у житті суспільства і держави говорив Н. Макіавеллі у своєму трактаті «Государ». Він вважав конфлікт універсальною ознакою суспільства, пояснюючи це природною порочністю людини. Томас Гоббс поряд зі своєю концепцією війни "всіх проти всіх" говорив про одну з головних причин конфліктів - це притаманне людині почуття конкуренції і бажання як мінімум рівності 3 іншими людьми.

Вивчення конфліктів в міжнародних відносинах як напрям наукових досліджень стартує в XX ст. і починається перш за все, з вивчення війн як найбільш небезпечного виду конфлікту. К. Клаузевіц, прусський воєнний теоретик, дуже яскраво описав війну як політичне явище міжнародних відносин. Він характеризував іï як: «не просто політичний акт, а справжній інструмент політики, продовження політичних відносин, реалізація їх іншими методами» [2, с. 46]. Реймон Арон стверджував, що «війна має не меншу вартість сьогодні, аніж тоді, коли воно було написане. Війна як суспільний акт передбачає боротьбу різних воль, тобто боротьбу між політично організованими спільнотами» [2, с. 45]. Ця боротьба може відбуватись у найрізноманітніших формах, найжорсткішою 3 яких $\epsilon$ воєнна, пов'язана зі збройним насильством. 
Також безперечним лідером цього напрямку став Ганс Моргентау. Так, робота Г. Моргентау "Політичні відносини між націями. Боротьба за владу і мир», перше видання якої побачило світ в 1948 році, стала свого роду «Біблією» для багатьох поколінь як в самих США, так і в інших країнах Заходу. Влада держави невіддільна від іiі сили, яка виступає одним 3 вирішальних засобів забезпечення національної безпеки на міжнародній арені. «Загроза фізичного насильства, - писав Моргентау, - є органічним елементом політики... У міжнародній політиці військова сила, як загроза або потенціал, є найважливішим матеріальним фактором, що забезпечує політичну міць держави».

Головним мотивом вивчення війн був пошук способів їх запобігання.

Ця проблема починає хвилювати багатьох політиків, вчених, громадських і релігійних діячів у відповідь на технологічний прогрес кінця XIX ст., коли багаторазово збільшилася руйнівна здатність зброї і з'явилася зброя масового знищення. Перша i особливо Друга світова війна, розпочата в післявоєнний період гонка ядерних озброєнь стимулювали дослідження в даній області. Карл Дойтч, відомий американський політолог, писав в 1964 році: «У столітті ядерної зброї, якщо ми не знищимо війну, то війна, ймовірно, знищить більшість 3 нас. У наш час дослідження причин воєн і способів їх стримування, контролю i, нарешті, заборона всіх воєн стає вираженням прагнення людства до життя».

Після Першої світової війни головне завдання досліджень полягало в пошуку оптимальних стратегій правильної та переможної поведінки в війнах; вивчення можливостей обмеження руйнівних наслідків війн; вивчення можливостей балансу на межі війни без переходу до відкритих воєнних дій. Держава в цей період розглядалася як головна дійова особа в міжнародних відносинах, і тому спочатку саме держава і війни, які ведуть держави, були головним об'єктом дослідження.

Далі значущі дослідження, які стали класичними в області вивчення воєн і конфліктів, були здійснені Пітиримом Сорокіним, Квінсі Райтом і Льюїсом Річардсоном. Ці вчені зробили спробу порівняльного аналізу значного числа воєн і виявлення їх закономірностей. Вони були першими, хто намагався застосувати мову цифр, кількісні методи для дослідження збройних конфліктів на великому фактичному матеріалі. Так, П. Сорокін методологічно розділив внутрішні і зовнішні збройні конфлікти, при тому, що він виділяв загальні моменти в їх розвитку та аналізі. Особливістю його дослідження було використання кількісних методів дослідження цього "якісно-кількісного явища" через виділення "об'єктивних", сухих цифр. Сорокін вибрав три характеристики війни - тривалість, чисельність армії, число втрат. Він також ввів відносний показник - співвідношення числа втрат до чисельності населення.

В основі важливих дослідів теоретика лежала посилка про те, що "внутрішні і зовнішні заворушення - революції і війни - $є$ не чим іншим, як логічними і фактичними наслідками дезінтеграції". Необхідно підкреслити висновок Сорокіна про те, що «жоден взятий окремо фактор не може 
пояснити ні частоту, ні розподіл війн...». Сорокін закликав до комплексного вивчення цього явища, знаходження системних закономірностей. Він вважав, що більш продуктивним $\epsilon$ аналіз «причинності війни» виходячи 3 розуміння самого явища війни як «розриву організованих взаємин між державами». Квінсі Райт, американський політолог, теоретик міжнародних відносин, $\epsilon$ автором іншої класичної роботи - «Вивчення війни», опублікованої в 1942 році. Саме 3 цієї роботи, на думку багатьох дослідників, починається формування нового дослідницького напрямку - дослідження проблем світу (peaceresearch). Райт проаналізував сам феномен війни, проблеми дефініції явища i ті зміни, які зазнав феномен з XV ст., класифікував існуючі підходи у вивченні війни та їі причинності, виділив чотири рівні аналізу і виявлення причин війн. Відповідно до запропонованої методології Райт аналізує міждержавні відносини через призму боротьби за владу і силу i розробляє свою теорію балансу сил. На думку К. Райта, незважаючи на те значення, яке грала політика балансу сил у справі збереження стабільності, розвитку міжнародного співтовариства i міжнародного права, в майбутньому «найімовірніше саме ефективна міжнародна організація буде істотною умовою як для підтримки стабільного балансу сил, так i міжнародного права».

Райт розглядав співвідношення внутрішньої і зовнішньої політики, вплив внутрішніх факторів економічного, політичного, інституційного характеру на ймовірне виникнення воєн. К. Райт зробив висновок про те, що війни пов'язані 3 розвитком технологій, i особливо військових; законами, які відносяться до війни та іiі ініціації; з соціальною організацією i такими політичними об'єднаннями, як плем'я, нація, імперія і міжнародні організації; 3 поляризацією суспільства в думках і відносинах за основними цінностями. Райт запропонував своє трактування світу як динамічного балансу, що включає політичні, соціальні, культурні та технологічні фактори. Війна розглядається як наслідок порушення балансу. Райт стверджував, що подібний баланс сил виникає в міжнародній системі за допомогою певної загальної моделі відносин як між державами, так і у внутрішній політиці окремих країн. Ще одне дослідження було зроблено англійським фізиком Льюїсом Річардсоном. Його книга «Статистика смертельних сварок (сутичок)» була опублікована в 1960 році і часто називається класичним дослідженням в даній області. Ця робота була продовженням вивчення Л. Річардсона проблем війни в міжнародних відносинах iз застосуванням кількісних i математичних методів дослідження. [11] Слід підкреслити, що моделювання успішно застосовується і в інших підходах, в т. ч. в системному.

Системний підхід інтегрує основні аспекти попередніх підходів i широко використовується в конфліктологіі. Він став впроваджуватися в науку про міжнародні відносини в середині XX століття, коли ЕОМ полегшили завдання моделювання, побудови i розрахунку конкретних систем. Найбільш повно даний підхід описав Д. Істон у книзі "Системний 
аналіз політичного життя», який дозволяє вивчати систему міжнародних відносин з урахуванням взаємозв'язків иї елементів. [10]

Однак роботи П. Сорокіна, К. Райта і Л. Річардсона були першими великими дослідженнями проблем війни і миру на значному історичному матеріалі. У цих роботах були закладені методологічні та концептуальні основи подальших досліджень конфліктів у міжнародних відносинах.

У 1960-і роки були запропоновані нові теоретичні концепції, які багато в чому визначили подальше вивчення проблем миру, війни i конфлікту i значно відрізнялися від парадигм традиційного вивчення міжнародних відносин. Й. Галтунг продовжив розробку концепцій "негативного" i "позитивного" світу на основі теорії структурного насильства. Таким чином, докорінна зміна в дослідженнях світу i конфліктів на заході відбулася в 1960 році, коли норвежець І. Галтунг замість фокусування на дослідженнях причин конфліктів звернув увагу на вивчення умов для створення світу. Вважається, що саме $з$ цього моменту теорія конфлікту і теорії миру були злиті воєдино. І. Галтунг порівнює дослідження i практику 3 врегулювання конфліктів 3 медициною, де виділяються три основні завдання: - діагностика; - складання прогнозу; терапія.

У різноманітті конфліктів дослідження стали виявляти не унікальні особливості конкретної ситуації, а, навпаки, принципово нові моменти, що дозволяють вирішувати їх мирними засобами.

У колективній монографіï, яку написали Й. Галтунг, Карл Дж. Якобсон і Кай Ф. Бранд-Якобсон «У пошуках миру: Дорога до трансцендентного», запропоновано вирішення 45 найгостріших конфліктів минулого i сучасності. Запропоновано вирішення проблем кавказьких конфліктів, між Ізраїлем і Палестиною, в Афганістані, Кореї, Кашмірі, між Сходом і Заходом і т.д. Головна робота в області конфлікту Кеннет Боулдінга була опублікована в 1963 році - «Конфлікт і захист: Загальна теорія». Боулдінг запропонував розглядати загальні елементи i риси в розвитку конфлікту з тим, щоб створити загальну теорію конфлікту, яка дозволяла б аналізувати будь-який окремий випадок конфлікту. Боулдінг не заперечував існуючих відмінностей між різними типами конфлікту. Він писав, що «моделі конфліктів у міжнародних відносинах, безумовно, відрізняються від моделей конфліктів у сфері індустріальних i міжособистісних відносин. Важливо досліджувати не тільки елементи подібності в різних конфліктних ситуаціях, а й відмінності. Ці відмінності можуть залишитися незрозумілими без загальної теорії конфлікту, яка виступає як стандарт порівняння». Подальший розвиток загальна теорія конфлікту отримала в роботах Льюїса Крісберга.

Джон Бертон - австралійський політик і дипломат, з середини 1960-х років займається викладацькою та дослідницькою діяльністю, очолював Центр аналізу конфлікту в Лондоні, є одним із засновників Центру аналітичного вивчення і вирішення конфліктів при Університеті Джорджа Мейсона, штат Вірджинія, США. Дж. Бертон вважається провідним 
теоретиком в області вирішення соціальних і міжнародних конфліктів. Бертон був першим, хто став проводити відмінність між процесами врегулювання i вирішення конфліктів. Бертон $\epsilon$ прихильником ідей Й. Галтунга про структурну природу насилля і конфліктів.

Слід звернути увагу на теорією торгу В. Зартмана, за якою держави, які залучені в конфлікт, визнають, що існує його взаємоприйнятне рішення. При цьому одна зі сторін коригує свої цілі або ій вдається переконати іншу сторону прийняти іï пропозиції, або змінити свої умови [12].

Даний метод виключає вирішення конфлікту силовим або юридичним шляхом. Основою методу $є$ постійна взаємодія сторін. При цьому поступливість однієї сторони здатна спонукати іншу сторону твердо стояти на своїх вимогах. При непоступливості обох сторін досягнення компромісу i договору малоймовірно. Даний підхід ефективний для аналізу поведінки сторін у конфлікті, коли вони готові врегулювати розбіжності шляхом переговорів.

Серед недавніх публікацій, присвячених проблемі конфлікту в міжнародних відносинах, хотілося б також відзначити роботи Калеві Якко Холсті, Девіда Зінгера, Франка Пфетча і К. Роулоффа. Роботи цих авторів продовжують традицію комплексного вивчення внутрішніх і міжнародних збройних конфліктів 3 використанням емпіричних даних i кількісних методів дослідження. У цих роботах узагальнені результати досліджень, які проводилися аналітичними центрами в різних країнах. Важливим напрямком цих досліджень є створення та оновлення баз даних про збройні конфлікти.

В кінці XX ст. Ф. Брайар і М. Р. Джалілі висунули засновану на системному підході концепцію-детермінант зовнішньої політики, ідея якої полягає в тому, що внутрішні і зовнішні чинники впливають на зовнішню політику держави, тісно взаємодіючи один з другом (Braillard Ph., Djalili M.-R. Les relations intemationales. Paris. 1990).

При цьому вони виділили наступні три групи міжнародних конфліктів, які відрізняються за своєю природою, мотивацією їх учасників і масштабами:

1. Класичні міждержавні конфлікти, міждержавні конфлікти 3 тенденцією до інтеграції, національно-визвольні війни тощо.

2. Територіальні та не територіальні конфлікти (можуть мати соціально-економічні, ідеологічні мотиви або ж витікати 3 волі до могутності).

3. Генералізовані (в них залучено велику кількість держав), які здатні перерости у світові конфлікти, а також регіональні, субрегіональні та обмежені (числом країн-учасниць).

C також інші класифікації, критеріями яких виступають причини i ступінь напруженості конфліктів, характер i форми їх протікання, тривалість і масштаби і т. д., однак на практиці кожна фаза конфлікту 
розвивається в рамках різних сфер функціонування суб'єктів конфлікту: політичної, військової, економічної, інформаційної, соціальної та екологічної.

Існують три підходи до регулювання конфліктів:

- правовий (або нормативний);

- примусово-переговорний;

- вирішення проблеми.

Перший спосіб вимагає консенсусу сторін. Домінуючу роль у врегулюванні конфліктів відіграє примусово-переговірний спосіб або метод торгу. Третій спосіб пов'язаний з досягненням безпеки суб'єкта конфлікту.

Найбільш часто використовуваним способом вирішення конфлікту $\epsilon$ прямі і непрямі насильницькі дії. Практика свідчить про збереження примату військового насильства у вирішенні протиріч. У мирний час воно використовується як загроза застосування військової сили, що в політичному лексиконі прийнято називати «стримуванням» або «залякуванням». Останнє десятиліття дає чимало прикладів використання інших насильницьких способів політичного, економічного, інформаційнопсихологічного та іншого характеру впливу на суб'єкти конфліктів.

У запобіганні та врегулюванні конфлікту важливу роль грають ненасильницькі дії і, перш за все, переговори.

У вітчизняній науці вивчення міжнародних конфліктів стало розвиватися відносно недавно, хоча сама проблема конфлікту розглядалася певною мірою різними науками i в радянський період. Домінування марксистсько-ленінської теорії у вітчизняній науці призводило до парадоксальної ситуації. Марксизм у західній соціальній та політичній науці розглядається як одна 3 основних теорій конфлікту. Саме тому вивчення міжнародних конфліктів отримують потужний імпульс розвитку на початку 1990-х років, після зникнення жорсткої ідеологічної цензури у вітчизняній науці. У працях А. Я. Анцупова та А. І. Шипілова відзначається, що перші роботи, присвячені проблемі конфлікту, з'явилися в 1924 році, але до 1990 року проблема конфлікту вивчалася досить мало. Власне міжнародники завжди зверталися до аналізу конфліктів і способів їх врегулювання як необхідної задачі зовнішньої політики, проте в 1990-і роки відбувається перегляд методології і змісту досліджень в умовах трансформації світової системи і зміни наукових парадигм. Загальні та спеціальні питання конфліктів у міжнародних відносинах знаходять відображення в роботах К. С. Гаджієва, А. В. Дмитрієва, В. А. Кременюка, Н. А. Косолапова, М. М. Лебедєву, Д. Б. Малишеву, П. А. Циганкова, Д. М. Фельдмана, М. А. Хрустальова та інших.

Всю тематику політичних конфліктів ми умовно розділили на наступні види: тероризм i екстремізм, міждержавні та регіональні конфлікти, етнополітичні та національні конфлікти, загальні аспекти вивчення політичних конфліктів. 
Зростання терористичної активності та екстремізму стало новою глобальною проблемою в усьому світі, що, в свою чергу, призвело до збільшення числа досліджень в даній області. Серед авторів, що вивчають дану проблематику, необхідно відзначити П. В. Масичева, Н. В. Муращенкову, Е. А. Степанову.

Міждержавні та регіональні конфлікти також мають високий відсоток досліджень і детально вивчені в працях Н. С. Андріанова, О. Р. Баймлера, А. І. Кольби, М. Н. Котова, Н. В. Штанські.

Загальні питання 3 вивчення політичних конфліктів розглянуті в працях А. В. Горностаєва, А. А. Насибулліна, А. В. Петрушиної.

Говорячи про етнічні та національні конфлікти, необхідно відзначити дослідження Л. А. Ахмадієвої, А. С. Бердникова, М. В. Невзорова, О. О. Чорних та ін.

Для врегулювання та вирішення існуючих конфліктів і попередження нових необхідно визначати предмет, об'єкт і суб'єкти конфлікту, і на їх основі виробити стратегію і механізм управління конфліктом. Одним 3 нових механізмів управління конфліктами $є$ "гуманітарна інтервенція". Їх проводять західні держави для реалізації своїх геополітичних інтересів i цілей під приводом гуманітарної допомоги державі та іiі населенню. Прикладами є інтервенції в Югославію, Боснію, Афганістан, Ірак, Лівію, Сирію [1].

"Гуманітарна інтервенція" не має міжнародних легітимних підстав i являє собою прикриття для реалізації коаліцією своїх геополітичних інтересів і сценаріїв, що передбачають насильницьку зміну неугодного режиму, встановлення військово-політичного контролю над регіоном i його ресурсами.

Підводячи підсумок, можна стверджувати, що дослідження в області конфліктології залишаються актуальними, але їх сутність все більше набуває політичного забарвлення і аналіз міжнародних конфліктів свідчить про те, що поки ще немає підстав говорити про зниження рівня конфліктної напруженості світової системи. Разом з тим змінився характер міжнародних конфліктів, з'явилися нові невійськові конфлікти, розширився склад можливих учасників конфліктів, а також весь спектр джерел і загроз міжнародній безпеці і стабільності.

Об'єктивні причини сучасних міжнародних конфліктів кроються в структурних дисфункціях сучасної системи міжнародних відносин. Сама міжнародна система перебуває у вкрай нестабільному стані. Зростанню конфліктної напруженості сприяє i той факт, що найбільш потужна держава світу для виконання своїх завдань і демонстрації силової переваги використовує таку стратегію управління конфліктами, як організація i підтримка конфліктної взаємодії.

Таким чином, міжнародна ситуація, що складається, вимагає розробки нових більш ефективних методів і механізмів управління міжнародними конфліктами. 


\section{Jimepamypa:}

1. Альтернативні підходи до розв'язання конфліктів: теорія і практика застосування / Уклад.: Н. Гайдук, І. Сенюта, О. Бік, Х. Тешко. Львів: ПАІС, 2007. 296 с.

2. Арон Р. Мир і Війна між націями / Р. Арон. - К., 2000.

3. Багінський А. В. Реконцептуалізація модерної держави: автономія, спроможність, належне урядування та конфлікти // Вісник Національного технічного університету України «Київський політехнічний інститут». Політологія. Соціологія. Право: зб. наук. праць. Київ, 2017. № 1/2 (33/34). С. 22-27.

4. Ледерак Дж. П. Розбудова миру: стале примирення в розділених суспільствах. Пер. $з$ англ. Д. Каратєєва та Л. Лозової. К.: Дух і літера, 2019. 256 с.

5. Шеллинг Т. Стратегия конфликта / Томас Шеллинг; пер. с англ. Т. Даниловой под ред. Ю. Кузнецова, К. Сонина. М.: ИРИСЭН, 2007. 366 с. (Серия «Международные отношения»).

6. Aiken, N. Identity, Reconciliation and Transitional Justice: Overcoming Intractability in Divided Societies, Transitional Justice Routledge, Oxon: 2013. 280 p.

7. Aiken, N. Learning to Live Together: Transitional Justice and Intergroup Reconciliation in Northern Ireland // The International Journal of Transitional Justice, Vol. 4, 2010, 166-188.

8. Bar-Tal, Daniel, Chernyak-Hai, Lily Schori, Noa and Gundar, Ayelet. A sense of self perceived collective victimhood in intractable conflicts // International Review of Red Cross. Volume 91. Number 874. June 2009. P. 229-258.

9. Brett, Roddy (2017) The Role of Civil Society Actors in Peacemaking: The Case of Guatemala, Journal of Peacebuilding \& Development. 12:1. P. 49-64.

10. Easton D. A. Systems Analysis of Political Life. New York, 1965.

11. Richardson L. Arms and Insecurity: A Mathematical Study of the Causes and Origins of War / pacific Grove, Cal.: Box-wood Press, I960. P. 57-69.

12. Zartman I. William. Introduction in the $50 \%$ Solution, ed. I. W. Zartman, Garden City, 1976. P. 7-18.

\section{References:}

1. Al'ternatyvni pidkhodi do rozv'yazannya konfliktiv: teoriya i praktyka zastosuvannya (2007) [Alternative approaches to the establishment of conflicts: theory and practice of storing] / Uklad : N. Hayduk, I. Senyuta, O. Bik, KH. Teshka. L'viv: PAIS - Set up: N. Gaiduk, I. Senyuta, O. Bik, H. Teshko. Lviv: PAIS. 296 s. [in Ukrainian].

2. Aron R. (2000) Myr i Viyna mizh natsiyamy [Peace and War between Nations] / R.Aron. K.

3. Bahins'kiy A. V. (2017) Rekontseptualizatsiya modernoyi derzhavy: avtonomiya, spromozhnist', nalezhno uryaduvannya ta konflikty [Reconceptualization of a modern state: autonomy, ability, properly managed and conflikti] // Visnyk natsional'noho tekhnichnoho universytetu Ukrayiny «Kyyivs'kyy politekhnichnyy instytut». Politolohiya. Sotsiolohiya. Pravo: zb. nauk. prats'. Kyyiv - Bulletin of the National Technical University of Ukraine "Kiev Polytechnic Institute". Politics. Sociology. Right: zb. sciences. good. Kiev, № 1/2 (33/34). 22-27. [in Ukrainian].

4. Lederak Dzh. P. (2019) Rozbudova myru: stale prymyrennya v rozdilenikh suspil'stvakh. Per. z anhl. D. Karatyeyeva ta L. Lozovoyi. K . [Peacebuilding: sustainable reconciliation in divided societies. Per. from English D. Karateeva and L. Lozova. K.]: Dukh i litera, - Spirit and Letter. 256 s. [in Ukrainian].

5. Shellinh T. (2007) Stratehiya konfliktu [Schelling T. Conflict Strategy] / Tomas Shellinh; per. z anhl. T. Danylovoyi pid red. YU. Kuznyetsova, K. Sonina. M. : IRISEN Thomas Schelling; lane. with English T. Danilova, ed. Yu. Kuznetsova, K. Sonina. M. : IRISEN. 366 s. (Seriya «Mizhnarodni vidnosyny»). [in Ukrainian]. 
6. Aiken, N. Identity, Reconciliation and Transitional Justice: Overcoming Intractability in Divided Societies, Transitional Justice Routledge, Oxon: 2013. 280 p.

7. Aiken, N. Learning to Live Together: Transitional Justice and Intergroup Reconciliation in Northern Ireland // The International Journal of Transitional Justice, Vol. 4, 2010. 166-188.

8. Bar-Tal, Daniel, Chernyak-Hai, Lily Schori, Noa and Gundar, Ayelet. A sense of self perceived collective victimhood in intractable conflicts // International Review of Red Cross. Volume 91. Number 874. June 2009. 229-258.

9. Brett, Roddy (2017) The Role of Civil Society Actors in Peacemaking: The Case of Guatemala, Journal of Peacebuilding \& Development. 12: 1. P. 49-64.

10. Easton D. A. Systems Analysis of Political Life. New York, 1965.

11. Richardson L. Arms and Insecurity: A Mathematical Study of the Causes and Origins of War / pacific Grove, Cal.: Box-wood Press, I960. P. 57-69

12. Zartman I William. Introduction in the $50 \%$ Solution, ed. I.W. Zartman, Garden City, 1976. P. 7-18 